\title{
Genetic Variability Analysis of Yield and its Components in Niger [(Guizotia abyssinica (L. f.) Cass.]
}

\author{
Kusumlata Baghel*, J.L. Salam, R.R. Kanwar and R.R. Bhanwar
}

S.G. College of Agriculture and Research Station, Jagdalpur 494005 Chhattisgarh, India

*Corresponding author

\section{Keywords}

Seed Yield, Genetic variability, Guizotia abyssinica

Article Info

Accepted:

22 July 2018

Available Online:

10 August 2018

\section{A B S T R A C T}

The present study "Genetic variability analysis of yield and its components in Niger [(Guizotia abyssinica (L. f.) Cass.]" was carried out at the Instructional cum Research Farm of S.G. College of Agriculture and research station, Jagdalpur (C.G.) Indira Gandhi Krishi Vishwavidyalaya, Raipur (C.G.) during Kharif 2017. The experimental material comprised of 50 Niger germplasm and 3 check variety of Niger. The experimental materials were sown on September 2017 in RBD design with three replication with the objectives to estimate the genetic variability, heritability and genetic advance. Analysis of variance indicate that the mean sum of square due to genotypes were highly significant for all the characters. High genotypic coefficient of variation and phenotypic coefficient of variation were observed for capitulum per plant and seed yield per plant $(\mathrm{g})$. The high heritability was recorded for the trait days to maturity and straw yield $(\mathrm{g})$ followed by days to $50 \%$ flowering and oil content $(\%)$, plant height $(\mathrm{cm})$, capitulum per plant, seed yield per plant $(\mathrm{g})$ seed per capitulum, primary branches per plant and harvest index (\%). Genetic advance a percentage of mean recorded high for capitulum per plant, seed yield per plant $(\mathrm{g})$, seeds per capitulum, oil content $(\%)$, harvest index $(\%)$, primary branches per plant, plant height $(\mathrm{cm})$ and straw yield $(\mathrm{g})$.

\section{Introduction}

Niger [Guizotia abyssinica (L.f.) Cass.] belonging to family Asteraceae is minor oilseed crop with its center of diversity and origin in Ethiopia. Niger constitutes about 3\% of Indian and 50\% of Ethiopian oilseed production in the world. Niger is the only cultivated species of the genus Guizotia with a diploid plant chromosome number of $2 \mathrm{n}=2 \mathrm{x}=30$ (Bisen et al., 2016). Niger seed belongs to the same botanical family as sunflower and safflower (Compositae). There are six species of Guizotia with G. abyssinica being the only the cultivated species. It is a dicotyledonous herb, moderately to well branched and grows up to 2 meter in height (Jagtap et al., 2014). Baagoe (1974) has revised this genus and recognized following species: G. abyssinica (L. f.) Cass.; G. scabra (Vis.) Chiov. Subsp. scabra and subsp. schimperi (Sch. Bip.) Baagoe; G. arborescens I. Friis; G. reptans Hutch; G. villosa Sch. Bip. 
and G. zavattarii Lanza. Guizotia scabra contains two subspecies, scabra and schimperi. Guizotia scabra subsp. schimperi, known locally as 'mech,' is a common annual weed in Ethiopia (Murthy et al., 1995). There are both herbaceous and woody members as well as annual and perennial ones. $G$. abyssinica is easily distinguished from the other members of the taxon by its large achenes and large head size as well as ovate outer phyllaries (Dagne, 1994b). Niger is commonly known as ramtil, jagni or jatangi (Hindi), ramtal (Gujrati), karale or khurasani (Marathi), uhechellu (Kannada), payellu (Tamil), verrinuvvulu (Telugu), alashi (Oriya), sarguza (Bengali), ramtil (Punjabi) and sorguja (Assamese) in different parts of the country It is the lifeline of tribal agriculture and economy in India (Pandey et al., 2014).

It has high protein content and is semi-tolerant to salinity and performs well under poorly aerated soil conditions (Abebe, 1975). Niger grows well on wide range of soil types. Some strains are salt tolerant and it is a valuable attribute for an oilseed crop. Niger oil has good keeping quality with $70 \%$ unsaturated fatty acids free from toxins. It has an advantage of yielding oil and has good degree of tolerance to insect pests, diseases and attack of wild animals. It has good potential for soil conservation, land rehabilitation and as a biofertilizer, consequently the crop following Niger is always good (Bisen et al., 2016). Niger is indigenous to Ethiopia where it is grown in rotation with cereals and pulses. The African and Indian gene pools have diverged into distinct types. On both continents Niger germplasm has been collected and evaluated and is mostly conserved and documented at the Biodiversity Institute of Ethiopia and the Indian National Bureau of Plant Genetic Resources (including zonal centers). The Ethiopian germplasm is collected from farmer's fields and does not include breeding lines. In this monograph the major germplasm characterizations and evaluations at Holetta, Ethiopia and Jabalpur, India are summarized (Getinet and Teklewold 1995).

Niger (Guizotia abyssinica L. f.) is an important oilseed crop of tropical and subtropical countries like India, Ethiopia, East Africa, West Indies and Zimbabwe. India ranks first in area, production and export of Niger in the world. India and Ethiopia are two major producers in the world. Out of the total oilseed production, it contributes nearly 50 per cent and 3 per cent from Ethiopia and India, respectively. Mostly grown in tribal areas in India, it is considered as "lifeline of tribal agriculture and economy". It has been an important crop as it has the potentially to give sustainable yield under rainfed situation.(Patil et al., 2013.) G. abyssinica is cultivated in Ethiopia and the Indian sub continent as a source of edible oilseed (Murthy et al., 1993). Niger (Guizotia abyssinica L.) is an important oilseed crop of tropical and subtropical areas of the world. The quality of oil and its suitability for a particular purpose is it for industrial use or for human consumption depends on the proportion of the different fatty acids it contains. There are opportunities which favor cultivation of oilseeds in general in the country which ranges from import substitution of edible oils to export of high value seed and oil. Although efforts have been done to improve oil quality of Niger seed using various breeding strategies, such as genetically modify the degree of unsaturation in oils through genetic engineering (Kinney 1994; Chapman et al., 2001). The oil is considered good for health which is pale yellow with nutty taste and a pleasant odour and can be used as a substitute for olive oil provided it has good keeping quality and selflife. Out of the total oilseed production, it contributes nearly $50 \%$ and $3 \%$ from Ethiopia and India, respectively. Niger is cultivated mainly for its high-quality edible oil amounting to $30-50 \%$ of seed weight (Seegler, 
1983). Niger is grown over an area of about 3 lakh ha in India in 10 States, with larger area in Chhattisgarh, MP, Maharashtra and Odisa. In India area is 2.61 lakh hectare, production $0.84 \mathrm{MT}$ and yield $3.21 \mathrm{q} / \mathrm{ha}$. In Chhattisgarh area is 0.63 lakh hectare, production $0.11 \mathrm{MT}$ and production $1.74 \mathrm{q} /$ ha (Anonymous, 2016). In Bastar area is 19.09 ('000) hectare, production $6.4 \mathrm{~T}$ and yield $231.1 \mathrm{~kg} / \mathrm{ha}$ (Anonymous, 2009a).

\section{Materials and Methods}

\section{Experimental site}

The present study "Genetic variability analysis of yield and its components in Niger [(Guizotia abyssinica (L. f.) Cass.]" was carried out at the Instructional cum Research Farm of S.G. College of Agriculture and research station, Jagdalpur (C.G.) Indira Gandhi Krishi Vishwavidyalaya Raipur (C.G. during) during Kharif 2017. The Bastar plateau zone which comes under zone VII Eastern ghat and plateau zone of Indian Agroclimatic Zone identified by planning commission (Anonnymous, 2009b) (Fig. 1).

\section{Geographical situation and climate}

Jagdalpur is at $19.1071^{\circ}$ North latitude and $81.9535^{\circ}$ East longitude with an altitude of 569 meters above located mean sea level. The region has subtropical and humid climate. The maximum rainfall was received during the month of July 2017. The total rainfall 1677 mm was received during crop season 2017. The periodic meteorological data (Kharif 2017) pertaining to weekly rainfall, minimum and maximum temperatures, relative humidity, evaporation and bright sunshine hours of entire crop growing period have been presented in Appendix. The experimental material comprised of 50 Niger germplasm and 3 check variety of Niger. The experimental materials were sown on $11^{\text {th }}$
September 2017 under RBD design with three replication in kharif season. Net plot size was $1.0 \times 2.0 \mathrm{~m}$, under this plot size, plot to plot distance $30 \mathrm{~cm}$, Row to row distance of $25 \mathrm{~cm}$ and plant to plant distance of $10 \mathrm{~cm}$ were maintained. Five competitive plants were randomly selected from each replications and plots and tagged each five plants. All agronomic practices were followed recommended package of practices to raise best for Niger. The experimental material comprised of 50 Niger germplasm and 3 check variety of Niger. The experimental materials were sown on $11^{\text {th }}$ September 2017 under RBD design with three replication in kharif season. Net plot size was $1.0 \times 2.0 \mathrm{~m}$, under this plot size, plot to plot distance $30 \mathrm{~cm}$, Row to row distance of $25 \mathrm{~cm}$ and plant to plant distance of $10 \mathrm{~cm}$ were maintained. Five competitive plants were randomly selected from each replications and plots and tagged each five plants. All agronomic practices were followed recommended package of practices to raise best for Niger.

\section{Statistical analysis}

\section{Analysis of variance (ANOVA)}

Analysis of variance for the experiment conducted as per R.B.D. will be carried out by model as suggested by Panse and Sukhatme (1985). The ANOVA is a powerful statistical tool for tests of significance.

$Y i j=\mu+g i+r j+e i j$

Where, $\mathrm{i}=1,2,3 \ldots \mathrm{g}$

$\mathrm{j}=1,2,3 \ldots \mathrm{r}$

Yij $=$ Yield of $j^{\text {th }}$ genotype in $i^{\text {th }}$ replication

$\mu=$ General mean

gi $=$ Effect of $i^{\text {th }}$ replication

$\mathrm{rj}=$ Effect of $\mathrm{j}^{\text {th }}$ genotype

eij $=$ Uncontrolled variation associated with $i^{\text {th }}$

replication and $\mathrm{j}^{\text {th }}$ genotype

Parameters of variation 
Range: The range of the distribution was expressed by the limit of the smallest and the largest value of each observation.

Mean: This was found out by summing up of all the observations and dividing the sum by the number of observations.

Heritability: Heritability in broad sense $h^{2} b$ defined as the proportion of the genotypic variance to the total variance (phenotypic variance) was estimated by Hanson et al., (1956).

$h^{2} b(b s)=\frac{\sigma^{2} g}{\sigma^{2} p} \times 100$

where,

$\sigma^{2} \mathrm{~g}=$ genotypic variation

$\sigma^{2} \mathrm{p}=$ phenotypic variation

Genetic advance: The expected genetic advance (G.A.) was calculated as per the method suggested by Johnson et al., (1955).

$\Delta \mathrm{G} . \mathrm{A} .=\mathrm{K} \cdot \sigma \mathrm{p} \cdot \mathrm{h}^{2}$

where,

$\mathrm{K}=$ Constant (Standard selection differential) having value of 2.06 at $5 \%$ selection intensity.

$\sigma \mathrm{p}=$ Phenotypic standard deviation.

$\mathrm{h}^{2}=$ Heritability estimate.

Genetic advance as percentage of mean: Genetic advance as percentage of mean was calculated by the following formula:

Genetic advance as $\%$ of mean $=\frac{G A}{\text { Mean }} \times$

100

where,

$\mathrm{GA}=$ Genetic Advance

Genotypic and phenotypic co-efficient of variation: The genotypic and phenotypic coefficient of variation were calculated using formulae the following suggested by Burton (1952).

$\operatorname{GCV}(\%)=\frac{\sqrt{\sigma^{2} g}}{\text { Mean }} \times 100$

$\operatorname{PCV}(\%)=\frac{\sqrt{\sigma^{2} \mathrm{p}}}{\text { Mean }} \times 100$

Where,

$\mathrm{GCV}=$ Genotypic co-efficient of

variation

$\mathrm{PCV}=$ Phenotypic co-efficient of variation

\section{Results and Discussion}

\section{Genetic variability parameters}

\section{Analysis of variance}

Analysis of variance indicate that the mean sum of square due to genotypes were highly significant for all the characters viz.,seed yield per plant, test weight (g), capitulam per plant, primary branches per plant, seed per capitulam, plant height at harvesting $(\mathrm{cm})$, days to $50 \%$ flowering, days to maturity, oil\%, straw yield (g) harvest index (\%). Similar results have been found by Panda and Sial. (2012) for days to $50 \%$ flowering, plant height, number of capitula per plant. Patil et al., (2013) observed similar findings for number of primary branches per plant, number of secondary branches per plant, plant height, number of capitulam per plant, days to maturity. Bisen et al., (2015) observed similar results for number of branches per plant, number of capitula per plant, plant height, oil content (\%), days to $50 \%$ flowering, days to maturity.

Parameters of genetic variability 
Genetic variability measures of variability include, mean, range, genotypic coefficient of variance, phenotypic coefficient of variance, heritability (broad sense) $\%$ genetic advance as per cent of mean for all characters. Genetic parameters of variation are discussed character wise here as under.

\section{Mean and range}

Mean is the sum of all observations in a sample divided by their number and range is the highest and lowest value of all the observation in a sample. The overall mean and range for yield and its components revealed that there is substantial amount of genetic variability present for most of the characters under study in Niger.

\section{Seed yield per plant}

Seed yield per plant ranged from $0.56 \mathrm{~g}$ (BN$13)$ to $1.39 \mathrm{~g}(\mathrm{BN}-48)$ with a mean value 0.93 . Maximum seed yield per plant was recorded in $\mathrm{BN}-48$ and minimum seed yield per plant was recorded in $\mathrm{BN}-13$. The genetic parameter of variation and analysis of variation where large amount of genetic variability available with this material under present investigation. So seed yield improvement along with component traits can be achieved either by direct and indirect selection. Similar results were reported by Sevantilal (2016) for seed yield per plant. Maximum seed was $1.51 \mathrm{~g}$ and minimum seed was $0.59 \mathrm{~g}$ recorded.

\section{Test weight (g)}

1000 seed weight ranged between $2.83 \mathrm{~g}$ (BN13) to $3.81 \mathrm{~g}$ (Birsa niger-3) with the average $3.35 \mathrm{~g}$ maximum 1000 seed weight was recorded in Birsa niger-3 and minimum 1000 seed weight was recorded in BN-13. Similar results have been found in Ahmad et al., (2016).

Number of capitulum per plant
The observation data of number of capitulam per plant ranged between $8.87(\mathrm{BN}-13)$ to 23.9 (Phule karala) with a general mean 16.37. The maximum number of capitulum per plant was observed in Phule Karala. and minimum number of capitulum per plant was observed in BN-13.

\section{Primary branches per plant}

The trait primary branches per plant ranges between $3.70(\mathrm{BN}-13)$ to $11.48(\mathrm{BN}-39)$ with an average value of 8.72 . The maximum number of primary branches was found in BN-39 and minimum number of primary branches per plant was found in $\mathrm{BN}-13$.

\section{Seeds per capitulum}

The variation of seeds per capitulum ranges $17.43(\mathrm{BN}-13)$ to $39.60(\mathrm{BN}-48)$ with an average 29.87. the maximum number of seeds per capitulum was recorded in $\mathrm{BN}-48$ and minimum number of seeds per capitulum was recorded in BN-13. Similar results have been reported by Tiwari et al., (2016) and Ahmad et al., (2016).

\section{Plant height}

The variation for plant height ranged 68.55 $\mathrm{cm}(\mathrm{BN}-13)$ to $141.54 \mathrm{~cm}(\mathrm{BN}-25)$ with a general mean $105.66 \mathrm{~cm}$. The highest plant height was observed in $\mathrm{BN}-25$ and the lowest plant height was observed in $\mathrm{BN}-13$.

\section{Days to $50 \%$ flowering}

Days to $50 \%$ flowering was ranged from $39.60(\mathrm{BN}-10)$ to $53.66(\mathrm{BN}-26)$ with an average value 45.98. The maximum day to $50 \%$ flowering was observed in $\mathrm{BN}-26$ and minimum days to $50 \%$ flowering were observed in BN-10.

Days to maturity 
Variation for days to maturity ranged between 77.00 (BN-11) to 98.00 (BN-24) with a general mean 86.17. The Maximum days to maturity was noticed in $\mathrm{BN}-11$, the minimum days to maturity was noticed in $\mathrm{BN}-24$. Similar results have been obtained by Tiwari et al (2016).

\section{Oil per centage}

Oil per centage ranged from $19.15 \%(\mathrm{BN}-20)$ to $37.89 \%$ (BN-48) with an average value $30.61 \%$. The maximum oil per cent was recorded in $\mathrm{BN}-48$ and minimum oil per cent was recorded in $\mathrm{BN}-20$.

\section{Harvest index}

Harvest index ranged from 15.83\% (BN-43) to $34.60 \%$ (BN-47) with a general mean $24.04 \%$. The maximum harvest index was observed in $\mathrm{BN}-47$ and minimum harvest index was observed in BN-43.

\section{Straw yield per plant}

Straw yield was ranged between 3.12g (BN-1) to $4.65 \mathrm{~g}(\mathrm{BN}-22)$ with an average value $3.86 \mathrm{~g}$. The maximum straw yield was noticed in $\mathrm{BN}$ 22 and minimum straw yield was noticed in BN-1 (Table 1).

\section{Genotypic and phenotypic coefficient of variation}

Genotypic and phenotypic coefficients of variation are simple measures of variability; these measures are commonly used for the assessment of variability. The relative values of coefficient give an idea about the magnitude of variability present in a genetic population. Thus, the components of variation such as genotypic coefficient of variation (GCV) and phenotypic coefficient of variation (PCV) were computed. Genotypic coefficient of variation (GCV) and phenotypic coefficient of variation (PCV) are categorized as low (less than 10\%), moderate (10-20\%) and high (more than 20\%) as suggested by Sivasubramanian and Madhavamenon (1973). The phenotypic coefficients of variation were marginally higher than the corresponding genotypic coefficient of variation indicated the influence of environment in the expression of the character under study.

High genotyphic coefficient of variation and phenotypic coefficient of variation were noticed for capitulum per plant $(23.61 \%$, $24.58 \%$ ) and seed yield per plant (g) $(22.34 \%, 23.73 \%)$. The moderate GCV and PCV was recorded for seeds per capitulum $(18.35 \%, 19.81 \%)$, primary branches per plant $(17.04 \%, 18.54 \%)$, harvest index $(\%)$ $(17.49 \%, 19.03 \%)$, oil percentage $(17.00 \%$, $17.27 \%)$, plant height $(\mathrm{cm})(12.00 \%$, $13.23 \%)$, straw yield $(\mathrm{g})(10.62 \%, 10.65 \%)$. The lowest GCV and PCV were recorded for days to $50 \%$ flowering $(8.05 \%, 8.18 \%), 1000$ seed weight $(\mathrm{g})(5.55 \%, 7.57 \%)$, days to maturity $(5.06 \%, 5.08 \%)$. Highest GCV and PCV were recorded for seed yield per plant by (Ahmad et al., 2016) and Rani et al., (2010) for plant height. Moderate GCV and PCV were recorded for primary branches per plant, seed per capitulum, plant height, by Tiwari et al., 2016. Low GCV and PCV were observed for days to $50 \%$ flowering, days to maturity by Ahmad et al., (2016). Similar results have been obtained by Tiwari et al., (2016) for days to $50 \%$ flowering, days to maturity, test weight $(\mathrm{g})$.

\section{Heritability (Broad sense)}

Heritability estimates the degree of variation in a phenotypic trait due to genetic variation between individuals in that population. It is useful in the selection of elite types from homozygous material (Table 2). 
Table.1 Analysis of variance for seed yield and its component in Niger at Jagdalpur (C.G.)

\begin{tabular}{|c|c|c|c|c|}
\hline S. No. & Characters & Mean Sum of Square & \\
\hline & & Replication & Genotypes & Error \\
\hline $\mathbf{1}$ & Seed yield per plant (g) & 0.010 & $0.134^{* *}$ & 0.005 \\
\hline $\mathbf{2}$ & Test weight (g) & 0.156 & $0.133^{* *}$ & 0.029 \\
\hline $\mathbf{3}$ & Capitulum per plant & 0.428 & $46.068^{* *}$ & 1.247 \\
\hline $\mathbf{4}$ & Primary branches per plant & 0.072 & $7.021^{* *}$ & 0.403 \\
\hline $\mathbf{5}$ & Seed per capitulum & 3.751 & $95.035^{* *}$ & 4.972 \\
\hline $\mathbf{6}$ & Plant height (cm) & 2.03 & $488.26^{* *}$ & 6.31 \\
\hline $\mathbf{7}$ & Days to 50\% flowering & 0.132 & $41.569^{* *}$ & 0.452 \\
\hline $\mathbf{8}$ & Days to Maturity & 0.169 & $57.161^{* *}$ & 0.189 \\
\hline $\mathbf{9}$ & Oil content (\%) & 0.648 & $82.133^{* *}$ & 0.871 \\
\hline $\mathbf{1 0}$ & Harvest index (\%) & 6.618 & $56.287^{* *}$ & 3.252 \\
\hline $\mathbf{1 1}$ & Straw yield (g) & 0.001 & $0.503^{* *}$ & 0.008 \\
\hline
\end{tabular}

*, **, Significant at 5 and 1 per cent levels, respectively.

Table.2 Genetic parameters of variation for seed yield and its component in Niger at Jagdalpur

\begin{tabular}{|c|c|c|c|c|c|c|c|c|}
\hline \multirow[t]{2}{*}{ S. No. } & \multirow[t]{2}{*}{ Character } & \multirow[t]{2}{*}{ Mean } & \multicolumn{2}{|c|}{ Range } & \multirow[t]{2}{*}{$\operatorname{PCV}(\%)$} & \multirow{2}{*}{$\begin{array}{l}\mathrm{GCV} \\
(\%)\end{array}$} & \multirow[t]{2}{*}{ Heritability } & \multirow{2}{*}{$\begin{array}{c}\text { Genetic advance as } \\
\% \text { of mean }\end{array}$} \\
\hline & & & Max. & Min. & & & & \\
\hline 1 & Seed yield per plant & 0.93 & 1.39 & 0.56 & 23.73 & 22.34 & 0.89 & 43.31 \\
\hline 2 & Test weight $(\mathrm{g})$ & 3.35 & 3.81 & 2.83 & 7.57 & 5.55 & 0.54 & 8.40 \\
\hline 3 & Capitulam per plant & 16.37 & 23.9 & 8.87 & 24.58 & 23.61 & 0.92 & 46.72 \\
\hline 4 & Primary branches per plant & 8.72 & 11.48 & 3.70 & 18.54 & 17.04 & 0.85 & 32.28 \\
\hline 5 & Seed per capitulam & 29.87 & 39.60 & 17.43 & 19.81 & 18.35 & 0.86 & 35.01 \\
\hline 6 & Plant height $(\mathrm{cm})$ & 105.66 & 141.54 & 68.55 & 13.23 & 12.00 & 0.96 & 24.24 \\
\hline 7 & Days to $50 \%$ flowering & 45.98 & 53.66 & 39.00 & 8.18 & 8.05 & 0.97 & 16.32 \\
\hline 8 & Days to Maturity & 86.17 & 98.00 & 77.00 & 5.08 & 5.06 & 0.99 & 10.37 \\
\hline 9 & Oil percentage & 30.61 & 37.89 & 19.51 & 17.27 & 17.00 & 0.97 & 34.47 \\
\hline 10 & Harvest index & 24.04 & 34.60 & 15.83 & 19.03 & 17.49 & 0.84 & 33.11 \\
\hline 11 & Straw yield & 3.86 & 4.65 & 3.12 & 10.65 & 10.62 & 0.99 & 21.82 \\
\hline
\end{tabular}


Fig.1 Weekly meteorological data

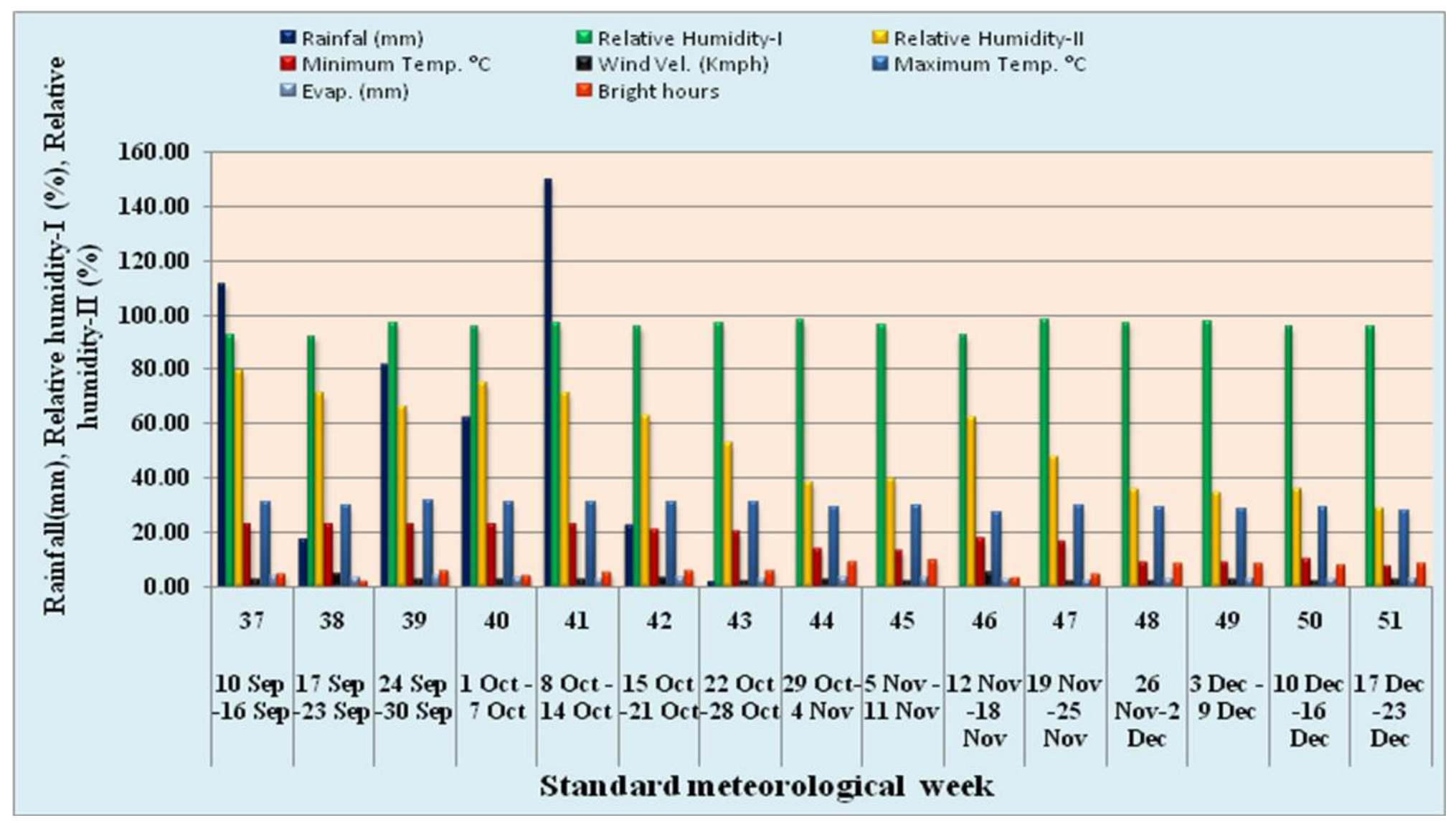


In the present experiment it has been made to estimate the heritability in broad sense by variance component analysis.

It is generally expressed in per cent viz., low (< $50 \%)$, moderate (50-7-\%), and high (> $70 \%$ ) as suggested by Robinson (1966). If heritability in broad sense is high it indicates characters are least influenced by environment and selection for improvement of such characters may be useful. If heritability in broad sense is low the characters are highly influenced by environmental effects and selection of such characters for genetic improvement is not useful due to masking effect of the environment on the genotypic effect.

In the present experiment most of the characters showed high estimates of broad sense heritability. The high heritability was recorded for the trait days to maturity $(99 \%)$ and straw yield (g) (99\%) followed by days to $50 \%$ flowering $(97 \%)$ and oil per centage (97\%), plant height $(\mathrm{cm})(96 \%)$, capitulum per plant $(92 \%)$, seed yield per plant $(\mathrm{g})$ $(89 \%)$, seed per capitulum $(86 \%)$, primary branches per plant $(85 \%)$, harvest index $\%$ $(84 \%)$. In this experiment the moderate heritability was recorded for the characters test weight (g) $(54 \%)$.

High heritability for seed yield per plant, capitulum per plant, seeds per capitulam, number of primary branches per plant, plant height days to maturity days to $50 \%$ flowering by (Tiwari et al., 2016) similar results have been found for number of capitulum per plant, plant height by (Patil et al., 2013) similar results have been found for number of capitulum per plant by (Ahmatd et al., 2016). Similar results have been found for seed yield per plant, oil per cent, days to maturity, days to $50 \%$ flowering, plant height, capitulum per plant by Vinod and Rajani (2016).

\section{Genetic advance}

Genetic advance is the improvement in the mean genotypic value of selected plants over the parental population. Heritability estimates along with genetic advance are normally more helpful in predicting gain under selection than heritability estimates alone. However it is not necessary that a character showing high heritability will also exhibit high genetic advance (Johnson et al., 1955).

The magnitude of genetic advance as per cent of mean was categorized as high (> $20 \%)$, moderate $(10 \%-20 \%)$, and low (< $10 \%$ ). If the value of genetic advance is high, it shows that the character is governed by additive genes and selection will be rewarding for improvement of such trait. If the value of genetic advance is low, it indicates that the character is governed by non additive genes may be useful. High genetic advance for seed yield per plant, number of capitulum per plant was recorded by Ahmad et al., (2016) similar results have been found for plant height by Tiwari et al., (2016) similar results have been reported by Rani et al., (2010) for plant height. Similar results have been found for plant height, primary branching per plant, seed yield per plant, capitulam per plant by Vinod and Rajani (2016). Genetic advance as per cent of mean (at 5\% intensity) recorded high for capitulam per plant $(46.72 \%)$, seed yield per plant (g) (43.31\%), seeds per capitulum $(35.01 \%)$, oil per cent $(34.47 \%)$, harvest index $(\%)(33.11 \%)$, primary branches per plant $(32.28 \%)$, plant height $(\mathrm{cm})(24.24 \%)$, straw yield (g) (21.82\%). Moderate genetic advance was recorded for days to $50 \%$ flowering (16.32\%), days to maturity $(10.37 \%)$, and low genetic advance was recorded for test weight $(\mathrm{g})(8.40 \%)$. High heritability estimates in broad sense along with high genetic advance as per cent of 
mean (at 5\% intensity) was recorded for capitulam per plant, seed yield per plant (g) seeds per capitulam, oil per cent, harvest index (\%), primary branches per plant, plant height $(\mathrm{cm})$ and straw yield $(\mathrm{g})$. It indicates that most likely the heritability is due to additive gene effects and selection may be effective.

\section{References}

Abebe, M. 1975. Ecophysiology of noog (Guizotia abyssinica Cass). Ph.D. Thesis. University of California, Riverside.

Ahmad, E., Aingh, M.K., Paul, A., Ansari, A.M., Singh, D.N. 2016. Genetic studies of yield and yield component of niger (guizotia Abyssinica Cass.) in rainfed condition of western plateau of Jharkhand. Int. J. Tropical Agric. 34(4): 1127.

Anonymous. 2016. Directorate of Economics and Statistics, Ministry of Agriculture and Farmers' Welfare, New Delhi.

Anonymous. 2009a. Government of Chhattisgarh. Agriculture Statistics. Commissioner Land Record, Raipur. pp.3-4.

Anonymous. 2009b. Government of Chhattisgarh. Agriculture Statistics. Commissioner Land Record, Raipur. pp.1-2.

Baagoe, J. 1974. The genus Guizotia (Compositae). A taxonomic revision. Bot. Tidsskrift 69:1- 39.

Bisen, R, Panday, A.K, Jain, S and Sahu, R. 2015. Genetic analysis in Niger (Guizotia Abyssinica Cass.) germplasm. Progressive Res. 10 (3): 1536-1539.

Bisen, R., Panday, A.K., Jain, S., Sahu, R. and Malviya, M. 2016. Estimation of genetic divergence among the niger germplasm. J. Ani. Pl. Sci., 26(5): 1320-1325.
Burton, D. W. 1952. Quantitative in-heritance in grasses. Proc. Sixth Inter. Grasslang Cong 1: 277-283.

Chapman, K.D., Austin-Brown, S., Sparace, S.A., Kinney, A.J., Ripp, K.G., Pirtle, I.L. and Pirtle

R.M. 2001. Transgenic cotton plants with increased seed oleic acid content. J. American Oil Chemists Society. 78: 941-947.

Dagne, K. 1994. Cytology, phylogeny and oil quality of Guizotia Cass (Compositae). Ph.D. Thesis. Addis Abeba University. Getinet, A. and A. Teklewold. 1995. An agronomic and seed-quality evaluation of Niger (Guizotia abyssinica Cass.) germplasm grown in Ethiopia. Plant Breed. 114:375-376.

Hanson GH, Robinson HF and Comstock RE. 1956. Biometrical studies of yield in segregating population of Korean Lespedeza. Agronomy Journal 48: 268-272.

Jagtap P.K, Sandipan P.B, Patel K.M and Patel M.C. 2014. Interrelationship between yield and yield attributing traits in niger germplasm. Trends in Biosciences 7(16): 2135-2136.

Johnson, H.W., Robinson, H.F. and Comstock, R.L.1955.Estimates of genetic and environmental variability in soybean. Agronomy J. 47: 314-318.

Kinney, A.J. 1994. Genetic modification of the storage lipids of plants. Current Opinion in Biotech. 5, 144-151.

Murthy, H.N., Hiremath, S.C. and Pyati, A.N. 1995. Genome classification in Guizotia (Asteraceae). Cytologia 60:67-73.

Murthy, H.N., Hiremath, S.C., and Salimath, S.S., 1993. Origin, evolution and genome differentiation in Guizotia abyssinica and its wild species. Theory Appl. Genet. 87:587592.

Panse, V. G. and Sukhatme, P. V. (1985). 
Statistical Methods for Agricultural Workers (Second edition), ICAR, New Delhi.

Panday, K. S., Sharma, Bisen, R., Jain, S., Malviya, M. and Ranganatha, A.R.G. 2014. Niger improvement: Current status and future strategies. J. Oilseeds Res., 31(2): 95-113.

Panda, S. and Sial P. 2012. Assessment of existing genetic variability and yield component analysis in niger [Guizotia Abyssinica (L. f.) Cass]. Indian J. Innovations Dev., 1(7): 511-514.

Patil, H.E., Mali, R.S., Giri, A.R. and Thawari, S.B. 2013. Genetic improvement in niger (Guizotia abyssinica) by using study of variability, correlation and path analysis. Int. J. Agric.Sci., 9(2): 671673.

Rani, M.G., Sreekanth, M., Rao, S.R. 2010. Genetic variability in morphological and quantitative characters in Niger (Guizotia abyssinica) germplasm. Crop Research., 40(1/3):132-134
Seegeler, C.J.P. 1983. Oil plants in Ethiopia Their taxonomy and agricultural significance. Centre for Agricultural Publication and Documentation, PUDOC, Wageningen.

Sevantilal, P.C.S. 2016.Variation and association studies for seed yield and related traits in Niger [Guizotia abyssinica (L.F.) Cass.] germplasm. M.Sc. (Ag) Thesis. Navsari Agricultural University, Gujarat.

Sivasubramanian, S. and Madhava, M. 1973. Genotypic and phenotypic variability in rice. Madras Agriculture Journal 60: 1093-1096.

Tiwari, V.N., Ahirwar, A.D., Rai, G.K. 2016. Estimation of genetic parameters of variability for yield and its attributing traits in Niger [(Guizotia abyssinica (L. f.) Cass.]. 16(1): 157-158

Vinod, K., Rajani, B. 2016. Genetic study for yield and yield attributing traits in Niger germplasm. Int. J. Agric. Sci., 8(56): 3044-3046.

\section{How to cite this article:}

Kusumlata Baghel, J.L. Salam, R.R. Kanwar and Bhanwar, R.R. 2018. Genetic Variability Analysis of Yield and its Components in Niger [(Guizotia abyssinica (L. f.) Cass.]. Int.J.Curr.Microbiol.App.Sci. 7(08): 4266-4276. doi: https://doi.org/10.20546/ijcmas.2018.708.447 